\title{
UPAYA PENINGKATAN PEMAHAMAN KONSEP MATEMATIKA MELALUI PENGGUNAAN ALAT PERAGA DAKON
}

\author{
R. Deni Vermana ${ }^{1}$, Helma Mustika ${ }^{2}$ \\ ${ }^{1,2}$ STKIP Insan Madani Airmolek \\ helmamustika@yahoo.com²
}

\begin{abstract}
Abstrak
Penelitian ini dilatarbelakangi dari permasalahan siswa dalam belajar matematika, seperti siswa beranggapan bahwa matematika merupakan mata pelajaran yang sulit dan kurang diminati. Anggapan tersebut muncul karena siswa kurang aktif, tidak serius dalam mengerjakan soal dan rasa ingin tahu yang kurang serta banyak memilih bermain dalam belajar matematika. Disaat pembelajaran berlangsung ditemukan siswa yang tertawa karena sibuk dengan aktivitasnya sendiri. Tujuan dari penelitian ini adalah untuk mengetahui ada peningkatan pemahaman konsep matematika melalui penggunaan Alat Peraga Dakon. Jenis Penelitian ini adalah Penelitian Tindakan Kelas (PTK) dengan teknik pengumpulan data dalam penelitian ini adalah tes pemahaman konsep matematika dan observasi. Dari hasil tes yang diperoleh menunjukan bahwa persentase ketuntasan $83,87 \%$ dengan target ketuntasan $75 \%$. Hal ini dapat disimpulkan bahwa penggunaan alat peraga dakon matematika dapat meningkatkan pemahaman konsep matematika siswa.
\end{abstract}

Kata kunci: penggunaan dakon matematika, pemahaman konsep matematika

\begin{abstract}
This research is motivated by the problems of students in learning mathematics, such as students who think that mathematics is a difficult subject and less desirable. This assumption arises because students are less active, not serious in working on problems and lack of curiosity and many choose to play in learning mathematics. During the learning process, students were found laughing because they were busy with their own activities. The purpose of this study was to determine that there was an increase in understanding of mathematical concepts through the use of Dakon Teaching Aids. This type of research is Classroom Action Research (PTK) with data collection techniques in this study is a test of understanding mathematical concepts and observation. From the test results obtained showed that the percentage of completeness was $83.87 \%$ with a target of $75 \%$ completeness. It can be concluded that the use of dakon mathematics teaching aids can improve students' understanding of mathematical concepts.
\end{abstract}

Keywords: the use of mathematical dakon, understanding of mathematical concepts

\section{PENDAHULUAN}

Menurut Karso dkk (2011) Pembelajaran matematika di SD merupakan salah satu kajian yang selalu menarik untuk dikemukakan karena adanya perbedaan karakteristik khususnya antara hakikat anak dan hakikat matematika. Untuk itu diperlukan adanya jembatan yang dapat menetralisir perbedaan atau pertentangan tersebut.

Berdasarkan hasil pengalaman selama mengajar yang dilakukan peneliti di SD Negeri 003 Belimbing terdapat permasalahan dalam pembelajaran diantaranya adalah proses pembelajaran matematika masih berlangsung secara klasikal, dimana guru menyampaikan materi dengan model pembelajaran langsung sehingga guru lebih berperan aktif dalam proses pembelajaran, sedangkan siswa hanya menerima informasi yang disampaikan guru, sehingga siswa bersifat pasif yang menimbulkan rasa jenuh dan bosan dalam diri siswa selama mengikuti pelajaran. Guru tidak menggunakan media/alat peraga dalam proses pembelajaran, guru hanya mengajarkan dengan cara-cara yang sudah ada sebelumnya. Ini mengakibatkan siswa kurang memahami materi yang diajarkan 
oleh guru dengan baik serta tidak adanya interaksi antar siswa selama proses pembelajaran. Sikap yang ditunjukan siswa terhadap pembelajaran matematika seperti yang sudah dijelaskan,merupakan lemahnya pemahaman konsep matematika siswa.

Menurut Subadi (2013)Salah satu pendukung keberhasilan pembelajaran dan hasil belajar adalah dengan menggunakan alat peraga dalam proses belajar mengajar khususnya pembelajaran matematika.Rochmad dalam Priambodo et. al (2014) menyatakan bahwa dalam pembelajaran matematika, khususnya dalam menanamkan konsep matematika, dengan menggunakan alat peraga menyebabkan pengalaman anak semakin luas berdasarkan sesuatu yang nyata. Untuk itu dalam penelitian ini, peneliti perlu menerapkan salah satu alternatif alat peraga yang digunakan yang mampu mengatasi masalah pemahaman konsep matematika siswa adalah dengan menggunakan alat peraga Dakon Matematika. Dakon matematika adalah suatu inovasi baru sebagai alat peraga dalam pembelajaran matematika.

Dakon matematika merupakan salah satu alat peraga yang menggabungkan antara permainan tradisional dan pembelajaran matematika. Sehingga diharapkan selain mampu menjadi alat peraga dalam pembelajaran matematika yag menyenangkan dan dapat meningkatkan penguasaan materi. Alat peraga dakon matematika juga diharapkan mampu melestarikan salah satu permainan tradisional indonesia yaitu Dakon. Alat peraga Dakon matematika ini di rancang dan dibuat sendiri oleh peneliti yang terbuat dari plastik sepanjang $100 \mathrm{~cm}$ dan lebar 25 $\mathrm{cm}$. Pada badan plastik bagian luar dilapisi dengan kertas minyak dan diberi tulisan Dakon Matematika KPK dan FPB. Dibadan tripleks itu terdapat lubang-lubang kecil yang terbagi menjadi 3 baris. Banyaknya lubang dapat disesuaikan dengan kebutuhan. Diatas setiap lubang dibarisan teratas dituliskan angka sesuai kebutuhan, adapun dibawa barisan terakhir terdapat lubang besar untuk wadah biji dakon. Sedangkan bijinya terbuat dari biji-bijian (biji Sawo), batu-batuan, kelereng atau plastik.

Aturan permainan Dakon matematika adalah dengan meletekkan biji-biji dakon satu persatu dilubang dakon sesuai dengan kelipatan atau perkalian faktor, permainan ini umumnya dimainkan oleh dua orang. Dalam menggunakan alat peraga ini ada beberapa alat yang terlebih dahulu dipersiapkan yaitu papan dakon matematika, biji dakon, dan spidol. Spidol digunakan untuk menuliskan bilangan pada papan dakon matematika.

Berbicara tentang pemahaman, Sanjaya (2009) mengemukakan pendapat bahwa pemahaman konsep adalah kemampuan siswa yang berupa penguasaan sejumlah materi pelajaran, tetapi mampu mengungkapkan kembali dalam bentuk lain yang mudah dimengerti, memberikan interprestasi data dan mampu mengaplikasi konsep yang sesuai dengan struktur kongnitif yang dimilikinya.

Adapun indikator dalam pemahaman konsep matematika ini adalah sebagai berikut:

1) Mampu menerangkan secara verbal mengenai apa yang telah dicapai.

2) Mampu memberikan contoh dan kontra dari konsep yang diberikan

3) Mampu mengembangkan konsep yang telah dipelajari.

\section{METODE}

Jenis penelitian ini adalah penelitian tindakan kelas (PTK). PTK merupakan suatu kegiatan reflektif bagi guru yang dapat dipergunakan untuk peningkatan proses pembelajaran yang telah dilakukan. Di dalam PTK terdapat 4 tahap yang tersusun menjadi sebuah siklus, yaitu tahap perencanaan (planning), tindakan (action), observasi (observation), refleksi (reflection).

Dalam penelitian ini, rata-rata kemampuan pemahaman konsep siswa pertindakan dalam satu siklus digunakan untuk mengetahui seberapa baik skor siswa secara keseluruhan pada kemampuan 
pemahaman konsep. Pertama penulis menggunakan rumus (Sudjana, 2002) :

Keterangan :

$$
X=\frac{\sum X}{n}
$$

$$
\begin{aligned}
& \mathrm{X}=\text { Mean } \\
& \mathrm{X}=\text { Skor Individual } \\
& \mathrm{n}=\text { Jumlah Siswa }
\end{aligned}
$$

Rumus yang digunakan untuk menghitung persentase lulus KKM adalah sebagai berikut (Sudijono, 2011)

$$
\begin{aligned}
& \qquad P=\frac{F}{N} X 100 \% \\
& \mathrm{P}=\text { Presentase siswayang } \\
& \text { mengalami lulus KKM } \\
& \mathrm{F}=\text { Frekuensi siswa lulus KKM } \\
& \mathrm{N}=\text { Banyaknya siswa }
\end{aligned}
$$

Setelah setiap hasil dihitung, skor diproses berdasarkan kriteria interpretasi skor sebagai berikut (Riduwan, 2010)

Persentase $0 \%-25 \%=$ sangatrendah

Persentase $26 \%-50 \%=$ rendah

Persentase $51 \%-75 \%=$ kuat

Persentase $76 \%-100 \%$ = sangatkuat

\section{HASIL PENELITIAN DAN PEMBAHASAN}

Hasil penelitian ini terdiri atas hasil pratindakan dan hasil tindakan. Hasil pratindakan berupa simulasi strategi cara penggunaan alat peraga dakon matematika sebelum tindakan diberikan. Sedangkan hasil tindakan berupa peningkatan pemahaman konsep matematika siswa dari setiap langkah pelaksanaan siklus I dan siklus II sebagai penggunaan dari alat peraga dakon matematika.

Pada tahap pratindakan diperoleh nilai pemahaman konsep matematika siswa melalui observasi tes awal. Dalam tes ini siswa yang mencapai KKM baru 8 orang dengan persentase $25 \%$.

Pada siklus I nilai test pemahaman konsep matematika siswa yang mencapai kriteria ketuntasan minimal (KKM) sebanyak 22 orang dengan persentase 70,96 $\%$. Dari hasil persentase terjadi peningkatan pemahaman konsep matematika siswa dikategorikan baik, tetapi belum memenuhi kriteria ketuntasan belajar yang telah ditentukan. Pada siklus II nilai test pemahaman konsep matematika siswa yang mencapai kriteria ketutasan minimal sebanyak 26 orang dengan persentase 83,87\%. Disamping itu juga dilihat dari hasil pengamatan keterlaksanaan pembelajaran dan aktivitas siswa selama pembelajaran sudah terlaksana dengan sangat baik. Peningkatan pemahaman konsep matematika siswa dari persentase jumlah siswa yang telah mencapi KKM dalam penelitian ini dilukiskan pada gambar grafik sebagai berikut.

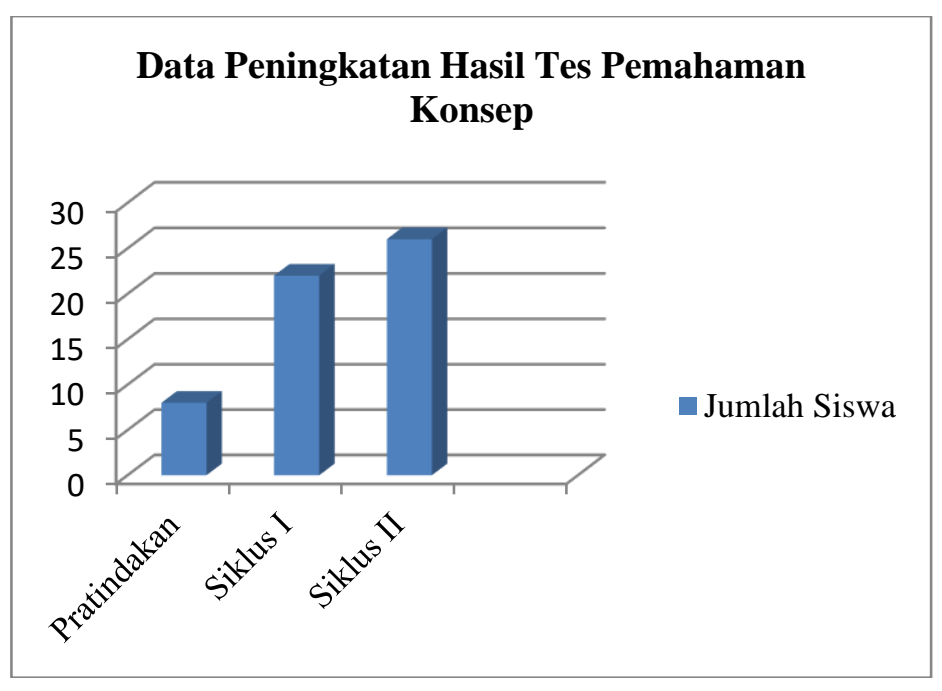

Gambar 1. Grafik Peningkatan Hasil Pemahaman Konsep 
Pemahaman konsep matematika siswa pratindakan masih terlihat rendah, namun setelah mengalami tindakan siklus I mengalami separuh peningkatan. Pada siklus II terlihat peningkatan dengan kategori baik sekali. Peningkatan pemahaman konsep matematika juga di pengaruhi oleh penggunaan alat peraga dakon matematika. Hal ini terlihat dari indikator-indikator kemampuan pemahaman konsep matematika sebagai berikut:
1. Mampu menerangkan secara verbal mengenai apa yang telah di capai

Kemampuan siswa menerangkan secara verbal mengenai apa yang telah dicapai dapat terlihat saat siswa mengerjakan soal didepan kelas. Setelah peneliti memperagakan bagaimana cara menentukan kelipatan persekutuan dan KPK. Peneliti memberi kesempatan kepada siswa untuk mencoba mengerjakan soal dikelas, seperti yang terlihat pada gambar 2

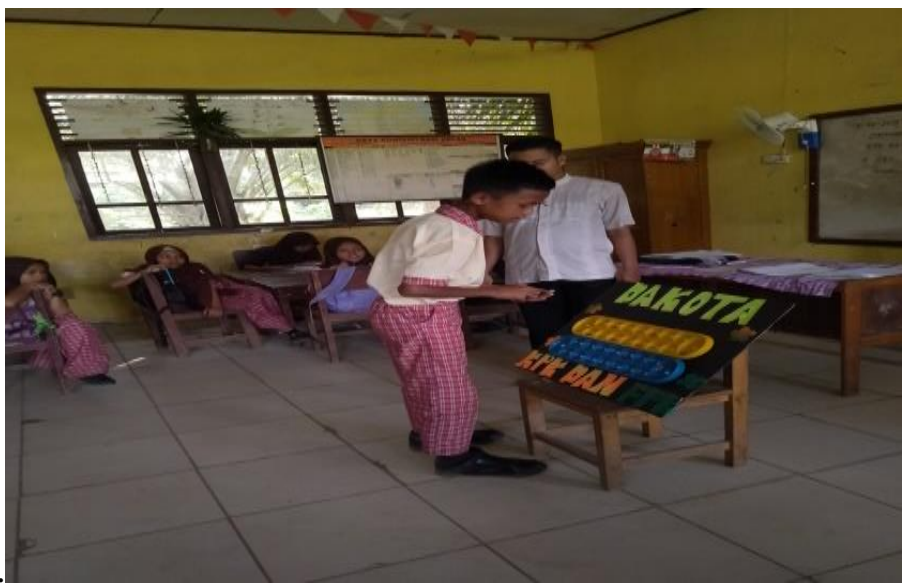

Gambar 2. Siswa mengerjakan soal di depan kelas

Berdasarkan gambar 2 kelihatan siswa sedang menggunakan alat peraga dakon matematika untuk mengerjakan soal di depan kelas. Setelah peneliti dan perwakilan siswa memberikan contoh bagaimana cara menentukan kelipatan persekutuan dan KPK, selanjutnya siswa berlatih mengerjakan Lembar Kerja Siswa (LKS). Berikut hasil lembar jawaban siswa pada materi kelipatan dan KPK.

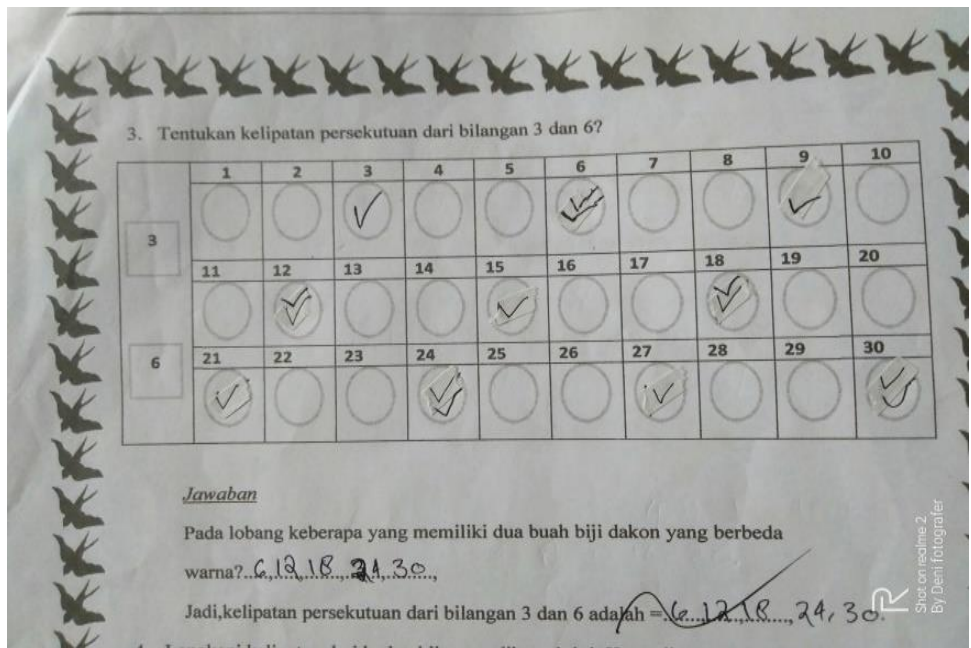

Gambar 3. Hasil Lembar Jawaban Siswa Materi Kelipatan Persekutuan

Berdasarkan gambar 3 siswa menjawab dengan benar kelipatan persekutuan. Siswa menjawab dengan memberikan simbol ceklis pada setiap lobang dakon yang 
merupakan kelipatan dari masing -masing bilangan, kemudian menentukan kelipatan persekutuan dengan cara melihat lobang dakon yang memiliki dua ceklis dalam satu lobangnya.
2. Mampu memberikan contoh dan kontra dari konsep yang diberikan

Kemampuan memberikan contoh dari konsep yang dipelajari terlihat saat siswa berada dalam pembelajaran dengan prosedur cara penggunaan alat peraga dakon matematika. Salah satu jawaban siswa dapat telihat pada gambar 4 .

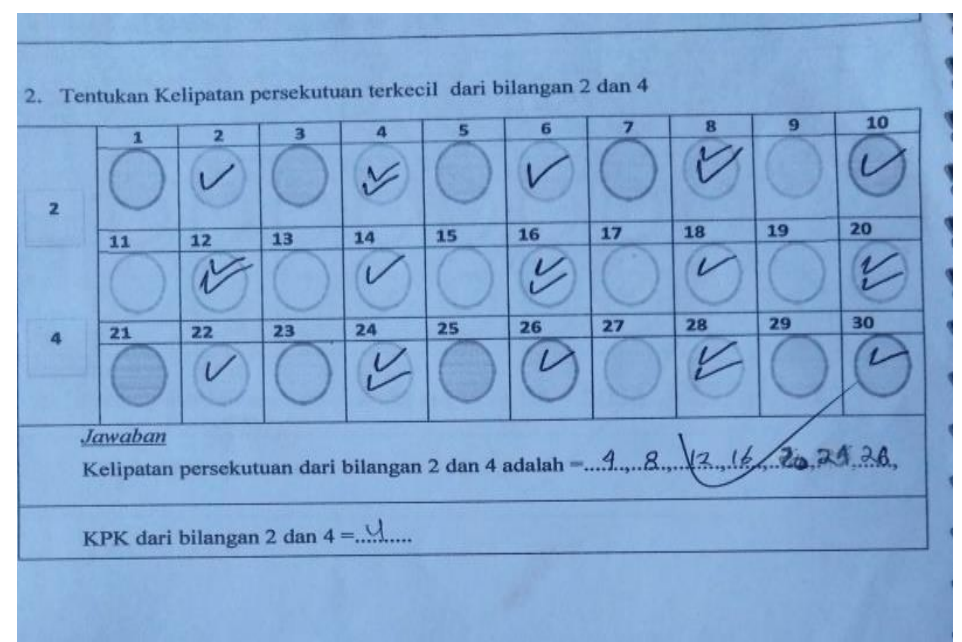

Gambar 4. Hasil Lembar Jawaban Siswa Menentukan KPK

Berdasarkan gambar 3 siswa sudah mampu menentukan KPK dengan terlebih dahulu menentukan kelipatan , kelipatan persekutuan kemudian KPK yang diperolehnya dari bilangan terkecil dari kelipatan persekutuan.
3. Mampu mengembangkan konsep yang telah dipelajari

Kemampuan mengembangkan konsep yang telah dipelajari terlihat pada siswa mengerjakan soal test pemahaman konsep matematika siswa, saat mengerjakan soal test siswa tampak menjawab dengan sungguh-sungguh. Salah satu jawaban siswa dapat terlihat pada gambar 5 .

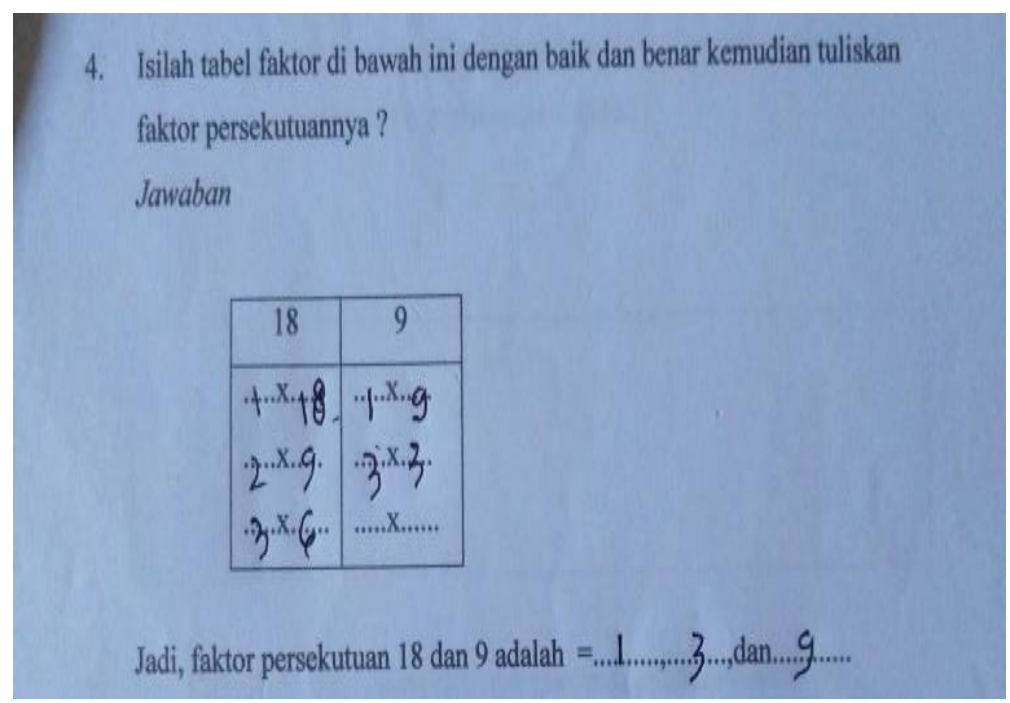

Gambar 5. Hasil Jawaban Siswa Menentukan Faktor Bilangan 
Pada tahapan ini siswa sudah mampu menyelesaikan soal dengan baik dan lancar. Ini dikarenakan siswa sudah mampu menyebutkan bilangan-bilangan yang menjadi faktor dari bilangan yang ditanyakan. Namun, masih terdapat beberapa siswa yang mengalami beberapa kesulitan, hal ini dikarenakan siswa tersebut belum hafal perkalian.

\section{SIMPULAN}

Persentase jumlah siswa yang mencapai KKM diatas 75 dari siklus I sebanyak 22 orang dengan persentase $70,96 \%$ dan siklus II sebanyak 26 orang dengan persentase $83,87 \%$. Peningkatan ini juga dapat dilihat dari lembar pengamatan kegiatan guru yang telah mencapai tingkat baik dan sangat baik. Dari siklus I pertemuan pertama memperoleh persentase $71 \%$ dan pertemuan ke dua $73 \%$. Pada siklus ke II pertemuan pertama memperoleh persentase $78 \%$ dan pertemuan ke dua sebanyak $81 \%$. Dari hasil tes yang diperoleh menunjukan bahwa penelitian telah mencapai persentase $83,87 \%$ dengan target ketuntasan 75\%. Hal ini dapat disimpulkan bahwa penggunaan alat peraga dakon matematika dapat meningkatkan pemahaman konsep matematika siswa

\section{REFERENSI}

Karso, dkk. (2011). Pendidikan Matematika I. Jakarta : Universitas Terbuka.

Priambodo, A. S. (2014). Keefektifan Model Learning Cycle Berbantuan Alat Peraga Terhadap Kemampuan Komunikasi Matematis. Unnes Journal of Mathematics Education, 3(2)

Riduwan. (2010). Skala Pengukuran Variabel-variabel Penelitian. Bandung: Alfabeta.

Sanjaya, W. (2009). Strategi Pembelajaran Berorientasi Standar Proses Pendidikan. Jakarta: Kencana Prenada Media Group.

Subadi. (2013). Meningkatkan Hasil Belajar Siswa Dengan Menggunakan Alat Peraga Melalui Model Pembelajaran Cooperative Learning Metode Stad Pada Materi Pokok Bangun
Ruang Sisi Datar Bagi Siswa. Jurnal Pendidikan Ekonomi IKIP Veteran Semarang, Vol.1No1 hal 11-18

Sudjana. 2002. Metode Statistika. Bandung: Tarsito. 